\title{
Sanal Gerçekliğin Reklam Stratejilerinde Kullanılmasına Yönelik Bir Değerlendirme
}

\section{An Evaluation on The Use of Virtual Reality in Advertising Strategies}

\section{Serhat Erdem}

Dr. Öğr. Üyesi, Atatürk Üniversitesi, Güzel Sanatlar Fakültesi, Sinema-TV Bölümü

email: serhaterdem@atauni.edu.tr (DORCID ID: https://orcid.org/0000-0002-3782-0147

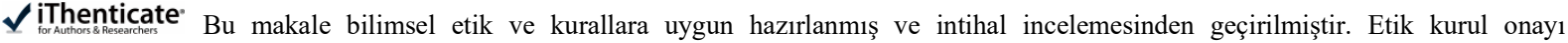
gerektirmemektedir.
\end{abstract}

Atıf (APA 6)/To cite this article

Erdem, S. (2021). Sanal gerçekliğin reklam stratejilerinde kullanılmasına yönelik bir değerlendirme. Atatürk Üniversitesi Güzel Sanatlar Enstitüsü Dergisi, 27(46), 241-248. https://doi.org/10.35247/ataunigsed.836847

Makale Gönderim Tarihi/Received: 14/12/2020

Makale Kabul Tarihi/Accepted: 07/02/2021

Makale Yayın Tarihi/Published: 30/03/2021

Review Article/Derleme Makale

$\ddot{O} z$

Teknolojinin akıl almaz bir hızla gelişmesi, internetin sosyal hayatın rutinleri arasına girmesi toplumsal hayatı birçok boyutuyla etkilemiştir. Teknolojinin gelişmesine paralel olarak ortaya çıkan kavramlardan biri de sanal gerçeklik kavramıdır. Sanal gerçeklik (Virtual Reality/VR) yapay ortamlar yaratarak gerçek gibi deneyimlenip etkileșim ortamı yaratan bilgisayar destekli sayısal platformları ifade etmek için kullanılan bir kavramdır. Sanal gerçeklik uygulamaları simülasyon başta olmak üzere birçok alanda (görsel, sanatlar, mimari, askeri, sağlık, eğitim, oyun, reklam) kullanılmaktadır. Bu çalışmanın amacı teknolojik gelișmeler sonucu ortaya çıan sanal gerçeklik uygulamalarının reklam stratejilerinde nasıl kullanıldığını ortaya koymaktır. Bu amaçla örnek olarak seçilen reklam uygulamaları çözümlenmiș ve sanal gerçekliğin reklam stratejilerinde nasıl kullanıldı̆̆ 1 tespit edilmeye çalışılmıştır.

Anahtar Kelimeler: Algı Yönetimi, Artırılmıș Gerçeklik (AR), Sanal Gerçeklik, Reklam

\begin{abstract}
The development of technology at an unbelievable speed and the internet becoming a routine of social life have affected social life in many ways. One of the concepts that emerged in parallel with the development of technology is the concept of virtual reality. Virtual reality (VR) is a concept used to express computer-aided digital platforms that create an environment of interaction by creating artificial environments that are experienced like real. Virtual reality applications are used in many areas (visual, arts, architecture, military, health, education, games, advertising), especially simulation. The aim of this study is to analyze how virtual reality applications emerging as a result of technological developments are used in advertising strategies. The advertising applications selected as an example were analyzed and how virtual reality was used in advertising strategies was tried to be explained.
\end{abstract}

Keywords: Perception Management, Augmented Reality (AR), Virtual Reality, Advertising

\section{Giriş}

Teknolojinin akıl almaz bir hızla gelişmesi gündelik hayatımızda ve toplumsalın birçok alanında değişim ve dönüşümü beraberinde getirmiştir. Teknolojik gelişmeler sonucunda neredeyse her gün yeni bir kavramla tanışmaktayız ve o kavram kısa bir zaman diliminde gündelik hayatımızın rutinleri arasındaki yerini almaktadır. Teknolojik gelişmelerden en çok etkilenen alanlardan biri de şüphesiz medya sektörüdür. Medya, gelişen teknolojilerin bütün olanaklarını sonuna kadar kullanmaktadır. Yeni medya aslında bilinmeyen tamamen yeni bir mecra olmaktan ziyade geleneksel medya ile benzer bir yapı sergilemektedir. Teknolojik olarak kullandığı özelliklerinden ötürü "yeni” medya olarak tanımlanmaktadır (Sirer, 2020, s. 46-47). Bu bağlamda düşündügümüzde yaşanan teknolojik gelişmelerin kitle iletişim araçlarının gelişmesini, medya ve iletişim alanında birçok yeni kavramın hayatımıza girmesini beraberinde getirdiğini ifade etmek mümkündür.

Kitle iletişim araçlarının etkisi birçok çalışmanın konusu olmuş ve kitle iletişim araçlarının toplumu bütün boyutlarıyla etkilediği ve toplumun şekillenmesinde belirleyici olduğu birçok araştırma sonucunda ortaya konmuştur. Örneğin televizyonun ses ve görüntüyü aynı anda ileterek, çok sayıda izleyiciye ulaştırması, yaratıcının belli bir etkileme amacıyla görsel ve sesli mesajları üreterek izleyiciye sunması (Kars, 2003, s. 9) bir kitle iletişim aracı olarak ortaya çıkan televizyon ile ilgili birçok çalışmanın yapılmasını beraberinde getirmiştir. Yeni medya olarak ifade edilen internetin günlük hayata dahil olması, teknolojiye erişim olanaklarının artması ve ucuzlaması ise (Bolat, 2020, s. 107), kitle iletişim araçlarının kullanım alanını genişlettiği için bu etki, üretimden pazarlamaya siyasetten sanata kısaca bütün alanlarda daha yoğun bir biçimde hissedilmeye başlanmıştır. Örneğin günümüzde yaygın biçimde kullanılan sosyal ağlar (twitter, facebook, instagram vd.) uluslararası siyaset ve diplomasi alanında mesajların ilgili muhataplara ulaşmasında kullanılan önemli bir araç olarak işlev görmektedir (Yaşar, 2020, s. 13). Sosyal medya platformlarının popüler birer iletişim mecrasına dönüşmesi, bu platformların kullanıcılarına kişisel alanlar sunarak kendi gündemlerini oluşturma ve bu gündemi etkileşime sunma imkânı tanıdığı için (Altincik, 2020, s. 33) işlevsel bir platform olarak birçok alanda kullanılmaktadır. Kısaca ürün ve hizmetlerin pazarlanmasından ideolojilerin aktarılıp yeniden üretilmesine kadar hemen hemen bütün alanlarda 
kitle iletişim araçlarının güçlü bir etkisi olduğu aşikardır. Bu araçları bu denli etkili kılan en önemli unsurların başında ise görsel, işitsel ve hareketli imgelerin birlikte kullanılmasını mümkün kılan özelliği gelmektedir (Akmeşe ve Akmeşe, 2020, s. 196).

Teknoloji ile birlikte son dönemlerde hayatımıza giren ve oldukça popülerleşen kavramlardan biri de sanal gerçeklik kavramıdır. Sanal gerçekliği, bilgisayar tabanlı üç boyutlu oyunlarda karşılaşılan ve kullanıcının bu ortama dahil olduğunda dünya ile ilişkisinin tamamen yok olduğu bir platform olarak ifade etmek mümkündür (İçten ve Bal, 2017a, s. 111). Sanal gerçeklik uygulamalarının geçmişi daha eskilere dayanmasına ve uzun süredir kullanılan bir teknoloji olmasına rağmen, son zamanlarda internet kullanımının yaygınlaşması ve kitlesel tüketicilerin internet teknolojileri ve ilgili araçlara erişim için ödemesi gereken maddi meblağların ucuzlaması gibi gelişmeler bu kavramın daha da ön plana çıkmasını sağladı (Alkan, 2019). Artırılmış gerçeklik ise gerçek dünyayla bağlantısını sürdüren, veri ve görüntülerin gerçek dünya görüntülerine eklenebildiği, sanal ve gerçek nesnelerin aynı platformda bir arada algılanmasına olanak sunan bir platform olarak tanımlanabilir (İçten ve Bal, $2017 \mathrm{~b}, \mathrm{~s}$. 401). Bütün bu uygulamaların ekonomik rakamlarla erişilebilir olması artırılmış gerçeklik (Augumented Reality AR) uygulamalarının son dönemlerde birçok alanda kullanılmaya başlanan etkili bir strateji olarak ön plana çıkmasında da etkili olmuştur. Artırılmış gerçeklik stratejisinin en çok kullanıldığı alanlardan biri de çalışmamızın konusunu oluşturan reklam ve pazarlama alanıdır. Sanal ve gerçek arasındaki farkı minimale indiren sanal gerçeklik sistemleri kullanıcıları aktif bir pozisyona taşıyarak, bu ortam iletileri üzerinde kullanıcı denetim ve etkileşimini arttırdığı ve kullanıcıyı deneyimin bir parçasına dönüştürdüğü için etkili bir biçimde kullanılmaktadır (Yengin ve Bayrak, 2018, s. 56). Bilindiği üzere küreselleşme politikaları çerçevesinde şekillenen ideolojik, kültürel ve ekonomik uygulamaların hayata geçirilmesiyle birlikte, tüketicinin aktifleşmesi ve tüketimin arttırılması için birçok farklı strateji uygulanmaktadır (Akmeşe, 2017, s. 134). Günümüz modern dünyasında gündelik hayatın rutinleri haline gelen tüketim sadece ihtiyaç duyduğumuz ürün ve hizmetleri değil, sürekli bir tüketme ve tükettikçe var olma anlayışı çerçevesinde geliştiği için reklam ve pazarlama önemli bir alan haline gelmiştir. Teknolojinin gelişmesi ve internet platformlarının yoğun bir şekilde kullanımı bu anlamda reklam ve pazarlama stratejileri açısından da hem yeni mecralar hem de farklı yöntem ve teknik kullanımını mümkün hale getirmiş durumda, bütün bu olanaklar da reklam alanında çalışan uzmanlar ve reklam verenler tarafından etkili bir biçimde kullanılmaktadır. Bu anlamda gerçekliğin sanal platformlara taşındığı ve gerçekliğin üç boyutlu biçimde tüketiciyle buluşturulduğu artırılmış gerçeklik stratejilerini içeren çalışmalar gün geçtikçe çoğalmaktadır. Alg1 yönetimi stratejileri ile marka ürün ve hizmetlerini kitlelerle buluşturmak ve kitleleri etkileyerek ürün ve hizmetlerini ön plana çıkarmaya çalışan reklam verenler artırılmış gerçeklik stratejilerinden yararlanmakta ve bu stratejileri tüketicinin algısını biçimlendirmek için kullanmaktadır. Bu bağlamda değişen ve dönüşen reklam ve pazarlama stratejileri incelendiğinde reklam ve teknoloji ilişkisi daha net bir biçimde ortaya çıkmaktadır.

\section{Yöntem}

Araştırma Betimsel modele dayalı Nitel bir araştırmadır. Bu çalışma, artırılmış gerçeklik (AR) stratejilerinin reklam alanında uygulanması, artırılmış gerçeklik ve algı yönetimi süreci arasındaki ilişkiyi odağına almaktadır. $\mathrm{Bu}$ amaçla çalışmaya dahil edilen örnek reklamlar amaçlı örnekleme yöntemi kullanılarak belirlenmiş ve çerçeveleme çözümlemesi yöntemi kullanılarak görüntü çerçevelemesi yöntemi ile analiz edilmiştir.

Amaçlı örnekleme, nitel araştırma geleneği içerisinde gelişen bir örnekleme yöntemidir (Yıldırım ve Şimşek, 2013, s. 135). Bu örnekleme yöntemi örnekleme dahil edilen kişi ya da objelerin, araştırmacının amacına en uygun yanıtı verebilecek, kişi veya objeler arasından seçilmesine dayanır. Seçimdeki temel ölçüt amaca uygunluktur (Aziz, 2008, s. 55). Çerçeveleme çözümlemesi ise bütün alanlarda kullanılabilecek işlevsel bir yöntem olarak bilinmektedir. Konusal çerçeveleme, içeriksel çerçeveleme ve görüntünün çerçevelenmesi olarak kategorize edilen çerçeveleme çözümlemesinde çerçeve içerisine dahli edilen tüm görsel ve işitsel unsurlar çözümlenmektedir (Akmeşe, 2020). Bu bağlamda amaçsal örnekleme yöntemi ile seçilen reklam filmleri, çerçeveleme çözümlemesi yöntemi ile analiz edilerek ilgili firmaların artırılmış gerçeklik stratejisi ile yaptığı reklam kampanyaları incelenmiş, artırılmış gerçeklik stratejilerinin kullanımı ve bu reklamların tüketiciler üzerinde nasıl bir etki yarattığı tespit edilmeye çalışılmıştır.

\section{Reklam ve Tüketim İlişkisi}

Temel amacı hedef kitleyi iletiler yoluyla bir ürün ve hizmeti almak için harekete geçirmek ve söz konusu ürün ve hizmetin alınmasını sağlamak olan reklamı pazarlama iletişiminin en eski formlarından biri olarak tanımlamak mümkündür (Yılmaz, 2014, s. 31). Tarihin ilk çağlarından itibaren adı reklam olarak anılmasa da hedef kitleyi bazı ürün ve hizmetlerin kullanım ve tüketimine sevk eden çalışmalar reklamın başlangıcını oluşturmaktadır. Sosyal, kültürel, ekonomik ve teknolojik gelişmelere paralel olarak reklam ve reklamcılık günümüzde önemli alanlardan biri olarak varlığını sürdürmektedir.

Arz ve talep dengesi düşünüldüğünde aynı hedef kitleye sunulan binlerce ürün, hizmet ve marka arasından sıyrılmak hedef kitleyi yakalamak ve ürün ve hizmeti sattırmak için fark yaratmak zorunda kalan üretici ve firmalar 
reklam kampanyaları ve stratejilerini kullanmak zorundadır. Reklamcılık teknolojik gelişmelerin sağladığı olanaklarla çok farklı uygulamaların kullanıldığı bir alan olarak karşımıza çıkmaktadır.

Reklam ve tüketim ilişkisi bağlamında bir değerlendirme yaptığımızda, reklamın amacı hedef kitleyi ürün ve hizmet ile ilgili bilgilendirmek ve o ürünü almasını sağlamak yani satışı artırmak iken, tüketim hedef kitlenin satın alma ve kullanma eylemini karşılamaktadır. Reklam ve tüketim ilişkisi ayrıca tüketim kültürünün ortaya çıkmasında ve yayılmasında da belirleyici bir unsurdur. Bu bağlamda tüketimin, serbest pazar koşullarında, kapitalist sistem, endüstrileşme ve tüketim ideolojisi yayan kitle iletişim araçlarının gelişmesi sonucunda toplumsal ve kültürel yapılar üzerinde belirgin bir etkiye sahip olduğunu ve bu etkinin, günümüz toplumları açısından daha da belirginleştiğini söylemek mümkündür (Uztuğ, 2008, s. 95). Reklamda artırılmış gerçeklik stratejilerinin kullanılması hedef kitlenin algısı üzerinde bir etki yaratarak kitleyi gerçeğe yakın bir görsel şölenin içerisine dahil ederek bir anlamda algısını biçimlendirmekte ve ürün veya hizmete talebini artırma noktasında diğer reklam ve pazarlama stratejilerine oranla daha etkili olduğu düşünülmektedir.

\subsection{Artırılmış Gerçeklik Uygulamaları ve Reklamlarda Kullanımı}

Teknolojinin gelişmesiyle birlikte artırılmış gerçeklik (AR) uygulamaları birçok alanda kullanılmaya başlanmıştır. Craig (2013) Understanding Augumented Reality, Consepts and Applications adlı eserinde AR uygulamalarının mevcut teknolojinin ötesine geçmemizi sağlayan bir aracı görevi üstlendiğini ve büyük resmi hayal etmemizi mümkün kıldığını ifade eder. Artırılmış gerçeklik uygulamalarının reklam ve pazarlama alanında son dönemlerde yaygın bir biçimde kullanan marka ve reklamlarını incelediğimizde sanal ve gerçeğin buluştuğu, eş zamanlı bir atmosfer yaratıldığı ve gerçekliğin hissedilmesini sağlayan üç boyutluluğun ekrana yansıtıldığı görülmektedir.AR uygulamaları ile ilgili yapılan akademik çalışmalar incelendiğinde bilişim teknolojileri ve uygulama alanları ile reklam ve pazarlama alanıyla ilgili çalışmaların yapıldığı görülmektedir. Yapılan çalışmalar AR uygulamalarının eğitim alanında kullanımı (Boz, 2019), AR uygulamalarının iletişim alanında kullanımı, AR uygulamaları ile geleneksel ve dijital ilişkisi (Bozat ve Dedelioğlu, 2018), AR uygulamaları ve Grafik tasarım ilişkisi (Gökçearslan, 2016), AR uygulamaları ve Dijital pazarlama ilişkisi (Köse ve Yengin, 2018), AR uygulamaları, sanal gerçeklik ve moda ilişkisi (Ağca ve Kozbekçi Ayranpınar, 2021) ve daha birçok alanda konu ile ilgili çalışmaların yapıldığ görülmektedir. Bu çalışmada amaçsal örnekleme yöntemi ile seçilen Domestos markasına ait çamaşır suyu, LC Waikiki markasına ait çocuk kıyafetleri, L’oreal Paris kozmetik ürünleri ve Filli boya reklamları çerçeveleme çözümlemesi yöntemi ile analiz edilmiştir.

\subsubsection{Domestos Mikroplart ve AR Uygulamalart}

Domestos markası, temizlik ürünleri içerisinde çamaşır suyu ile özdeşleşmiş bir marka olarak bilinmektedir. Domestos çamaşır suyu ile ilgili TV reklamları incelendiğinde genellikle ekranda mikrop karşıtı, çamaşıra zarar vermeyen bir ürün olarak tanıtıldığı görülmektedir. AR uygulamaları ile yapılan örnek reklamda Nişantaşı semtinde bir otobüs durağı tercih edilmiş, otobüs durağında bekleyen yolcular bir anda durağın cam duvarında üç boyutlu mikrop, virüs ve çeşitli haşereleri görünce önce kısa bir şok etkisi yaşıyor, sonrasında ise bunun bir AR uygulaması olduğunu fark ettikten sonra durak duvarı ile bir etkileşim içerisine girmekten ve ilgi göstermekten kendilerini alıkoyamıyorlar.

\section{Görsel 1}

Domestos Mikropları Nişantaşı 'nda

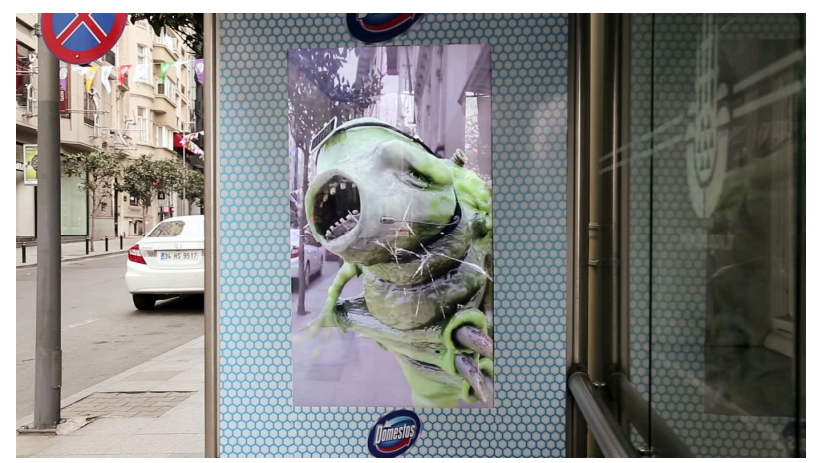

(Campaign Türkiye, 2015).

Görselde de görüldüğü gibi Domestos mikrobu otobüs durağının camına çarparak camı çatlatmakta ve artırılmış gerçeklik efektiyle gerçek bir arada sunularak hedef kitlenin dikkati çekilmeye çalışılmaktadır. 


\section{Görsel 2}

Domestos Mikropları Nişantaşı'nda

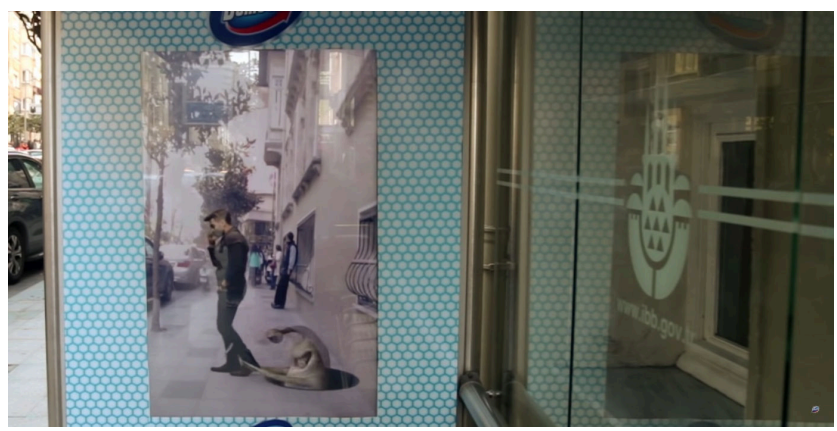

(Campaign Türkiye, 2015).

İkinci fotoğrafta ise caddede telefonla konuşan bir genç ve reklam için yaratılmış mikrop görseli bir arada görülmektedir. Kısaca artırılmış gerçekliğin gerçeklikle kesiştiği nokta olarak ifade edebileceğimiz bu kare AR uygulamalarının gerçek hayat ile sanalı nasıl bir arada ve gerçekçilik hissi vererek hedef kitleye sunduğunu bu görsel üzerinden somutlaştırmak mümkündür. Görüntü çerçevesine dahil edilen unsurların özenle seçildiği ve markanın imajını destekleyecek bir biçimde kurgulandığı gözlenmektedir.

\subsubsection{LC Waikiki “Yükle, Çalıştır, Yaklaştır, Canlandır” Sloganlı AR Uygulamalı Reklam}

LC Waikiki markası bu reklamda hedef kitle olarak belirlediği çocuklar için "Yükle, Çalıștır, Yaklaştır, Canlandır" sloganı ile AR uygulamalı 4D çocuk tişörtlerini ebeveyn ve çocukların beğenisine sunmuştur. Marka bu stratejiyi kullanarak teknoloji içerisine doğan çocukları hedef kitlesi olarak belirlemiştir. Marka ayrıca akıllı tablet ve telefonlar için Wear 4+ uygulaması ile bu 4D çocuk tişörtleri üzerine akıllı cihazı tuttuğunuzda, bu karakterlerin canlanan hareket eden versiyonlarını izleme olanağı sunacak bir destek programla hem reklam anlayışı hem de belirlediği hedef kitlesi açısından yeni bir vizyonla rakiplerinin karşısındaki yerini almıştır.

Uygulamanın 'Google Play’ mağazasındaki açıklamasını incelediğimizde; uygulamanın tanımı şu şekilde ifade ediliyor: "kıyafet koleksiyonunda gizlenmiş, basit görünen günlük kıyafetleri mucizevi bir hale getiren gizli sürprizleri keşfetmenin heyecan verici yolu". Marka ayrıca müşterilerine satın aldıkları takdirde bu kıyafetlerin yanında bir talimat broşürü ile destek sunmaktadır.

\section{Görsel 3}

AR İle Hareketlenen Karakterler

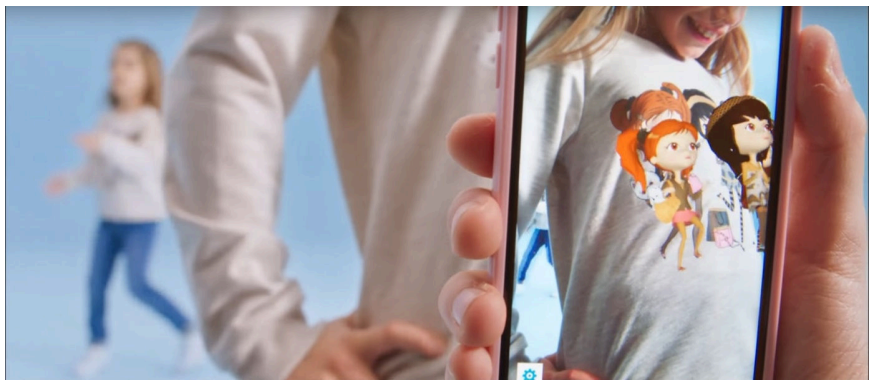

(LC Waikiki, t.y.).

\section{Görsel 4}

AR ile Canlanan Timsah

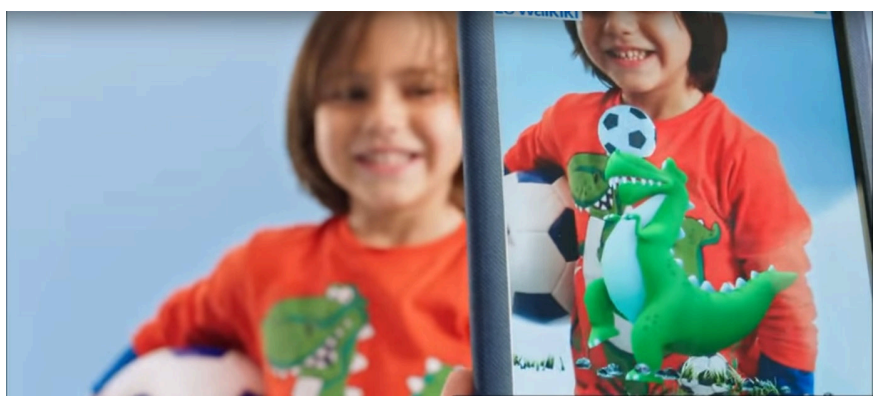

(LC Waikiki, t.y.). 
Reklamdan alınan iki görselde de görüldüğü gibi çocukların üzerinde yer alan giysilerdeki karakter ve kahramanlar akıllı tablet veya telefona yüklenen Wear 4+ uygulaması aracılığı ile hareketlilik kazanarak çocuklar ve karakterlerin bir arada olduğu ve çocukları bu artırılmış gerçekliğin içerisine dahil eden bir atmosfer oluşturularak hedef kitlenin ürüne karşı ilgisi uyandırılmaya çalışıldığı dikkat çekmektedir.

\subsubsection{L'Oréal Paris Make Up Genius Uygulamast}

AR uygulamalarını reklam stratejisi olarak kullanan bir diğer markada dünyaca ünlü güzellik markası olarak bilinen L'Oréal Paris. Marka hedef kitle olarak belirlediği kullanıcılara makyaj malzemelerini dijital ortamda kendi yüzlerinde test etme olanağı sunmaktadır. Kullanıcılar gerçek zamanlı bir makyaj uygulaması olarak geliştirilen Make Up Genius uygulaması aracılığıyla markaya ait bütün ürünleri kendi yüzlerinde test etme olanağına sahip olmaktadır. Ayrıca birçok ünlü makyaj tasarımcısına ait makyaj kombinasyonlarının da kullanılmasına olanak veren bu uygulama aracılığıyla ürünlerin satışını artırmak hedeflenmiştir.

\section{Görsel 5}

Make Up Genius Uygulaması

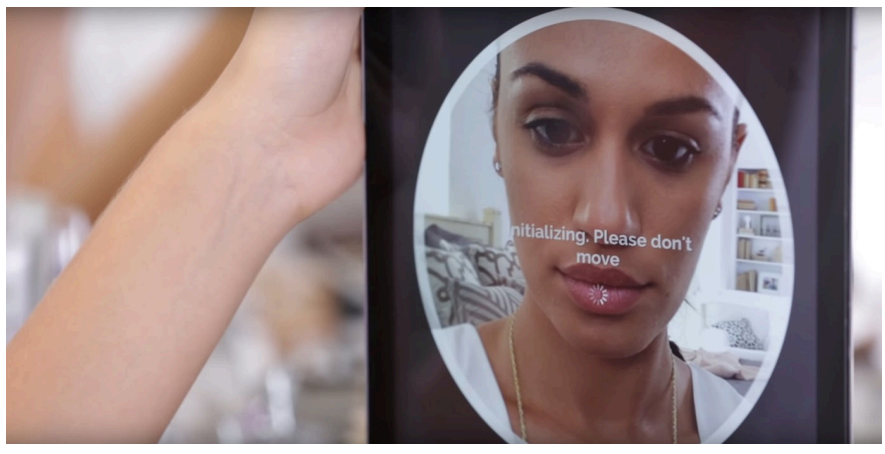

(Beauty 2.0, 2016).

\section{Görsel 6}

Kullanıcının Uyguladı̆̆ Sanal Göz Makyajı

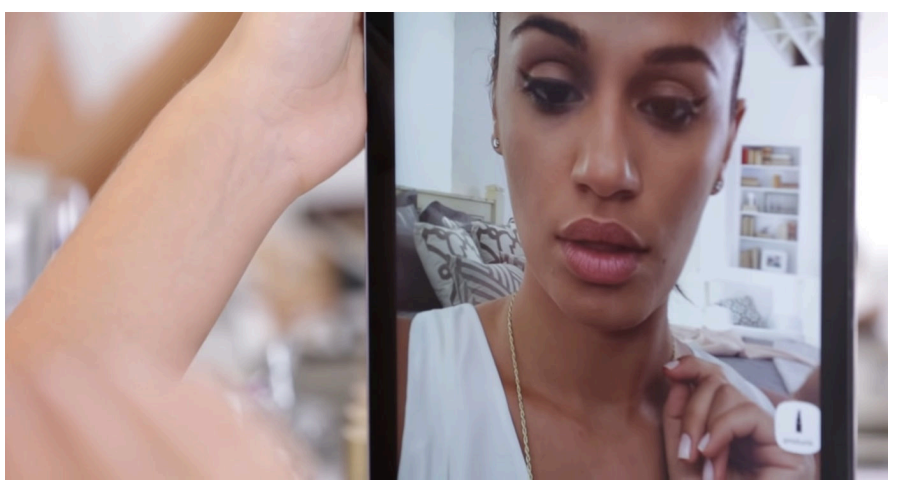

(Beauty 2.0, 2016).

\section{Görsel 7}

Kullanıcının Mă̆azada Test Ettiği Ruj Renkleri

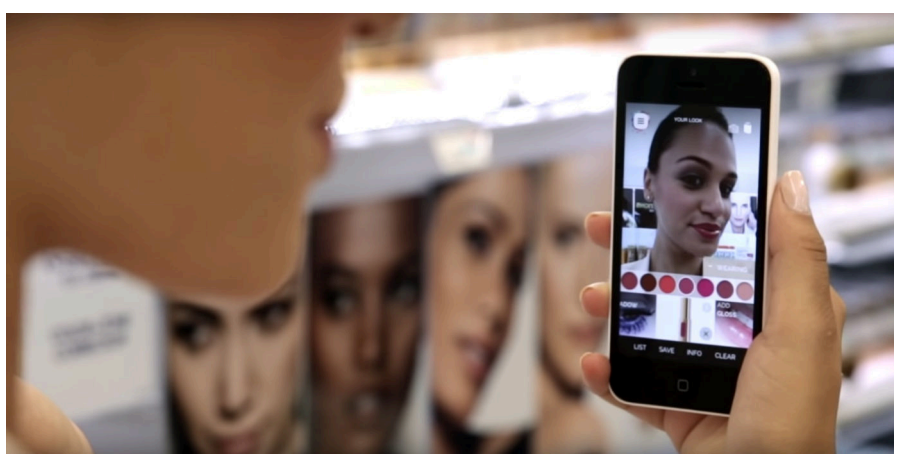

(Foto Especial, 2018). 
Görsellerde de görüldüğü üzere gerçeklik simülasyonu yaratılarak uygulama aracılığıyla kullanıcıların ürünleri kendi üzerlerinde test etme ve makyaj uygulamasını gerçek gibi görmeleri alışveriş ve ilgili ürünlerin daha çok satılması (özellikle online alışveriş bağlamında) noktasında belirleyici bir unsur olarak dikkat çekmektedir.

\subsubsection{Filli Boya ve Mimar Benim Uygulamast}

\section{Görsel 8}

Filli Boya Mimar Benim Uygulamast

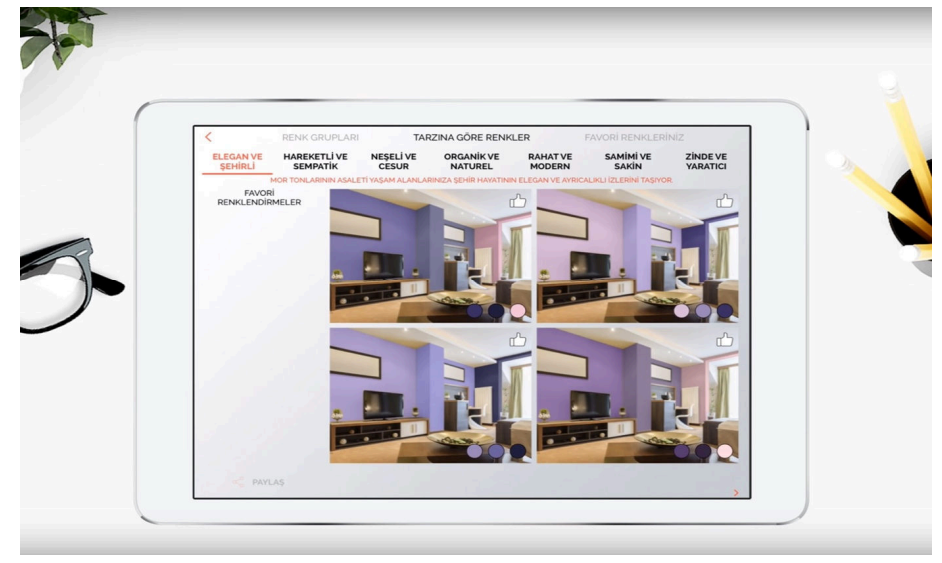

(Filli Boya, 2017).

Filli boya yaptığı Mimar Benim uygulaması ile hedef kitlesine ev, ofis ve benzeri yaşam alanlarını badana yapmadan önce dilediği renkte görme olanağı sunmaktadır. Bu uygulamayı kullanmak için boya badana yapılacak mekânın görselinin akıllı cihaza yüklenmesi gerekiyor. Uygulama aracılığıyla seçilen renk ilgili "görseldeki mekânı direk o renge boyuyor. Reklamın görüntü çerçevesi içerisine dahil edilen bilgilerin dışında kullanıcıların zihinlerinde canlandırdığı görselleri çerçeve içerisine dahil etme olanağı sunan bu platform AR uygulamalarının soyut olanı somutlaştırma ve kullanıcıyı aktif bir pozisyona getirme açıcından da dikkat çekmektedir.

\section{Sonuç ve Değerlendirme}

Teknolojinin gelişmesi, internetin hayatımıza girmesi sonrasında akıllı mobil cihazların gündelik rutinimiz haline gelmesi ve daha birçok gelişme sonucunda bütün alışkanlıklarımız bu yeniliklere paralel olarak değișim gösterdi. Reklam ve pazarlama alanında kullanılan stratejilerde teknolojik gelişmelere paralel olarak sürekli günceli yakalamaya çalışmaktadır. Instagram, facebook, twitter vb. sosyal ağlarla başlayan online reklam ve pazarlama stratejileri son dönemlerde teknoloji dünyasında adından sıklıkla söz ettiren artırılmış gerçeklik, 3B, simülasyonlar ve benzeri gelişmelerle devam etmektedir.

Artırılmış gerçeklik uygulamaları askeri alandan mimariye sağlık alanından reklam ve pazarlamaya kadar birçok alanda etkili ve işlevsel bir biçimde kullanılan teknolojik gelişmelerden biri olarak karşımıza çıkmaktadır. Medya alanında sinema filmlerinde, reklam ve pazarlama çalışmalarında kullanılan bu strateji özellikle son dönemlerde e-ticaret ve online alışveriş alanında ciddi bir değişim ve gelişime kapı aralamıştır. Google, youtube gibi dev internet firmaları başta olmak üzere, dünyaca ünlü araba markaları, kozmetik firmaları ve uluslararası şirketler tarafından reklam stratejisi olarak karşımıza çıkmaktadır.

Hedef kitlesine ürün ve hizmetini ulaştırmaya çalışan marka ve firmalar bu strateji sayesinde kullanıcıların uzaktan erişimle ürünlerini satın alınmadan AR teknolojisiyle bu ürünleri denemelerine ve deneyimlemelerine olanak sunmaktadır. Çalışmanın örneklemini oluşturan Domestos, LC Waikiki, L'oreal Paris, Filli boya reklamları detaylı bir biçimde analiz edildiğinde markanın AR teknolojisiyle hedef kitlesini yakaladığı, kullanıcılara gerçeklik hissi olanağı sunarak ürün ve hizmet ile etkileşim kurmasını kolaylaştırdığı ve sağladığı bu olanakların ürünün tercih edilmesi ve dikkat çekmesinde belirleyici olduğu gözlenmektedir.

Domestos reklamının görüntü çerçevesi göz önünde bulundurulduğunda hedef kitlede önce bir şok etkisi yaratırken, reklama maruz kalan kişilerin bu durumun farkına vardıktan sonra ilgili reklama ve karakterlere sempatik bir biçimde yaklaştığı, bu artırılmış gerçeklik uygulaması ile etkileşime geçerek fotoğraflar çektiği ve bu fotoğrafları sosyal ağlar aracılığıyla paylaşarak reklamın reklamının yapılmasına hatta uygulamanın yer aldığ reklamın dolaşıma girmesine katkı sağladığı gözlenmektedir. Bu anlamda da ilgili reklam oluşturulurken reklamın içerisine yerleştirilen kodlar ve mesajla aslında hedef kitlenin algısına yönelik bir çalışmayı da barındırdığını ifade etmek olanaklıdır.

LC Waikiki reklamının görüntü çerçevesinin içerisine dahil edilen unsurlar incelendiğinde benzer kod ve amaçları barındırdığı görülmektedir. Yaratılan sevimli kahraman karakterlerinin kıyafetler üzerinde yer alması, bu 
karakterlerin hareketli bir hale dönüşmesi ve hedef kitle olan kullanıcı ve karakteri bir platformda buluşturma hissi hedef kitle üzerinden düşünüldüğünde firmanın, çocukların ilgi ve algılarını etkilemeye yönelik stratejik bir çalışma yürüttüğü ve hedefinde başarılı olduğu görülmektedir.

L'oreal Paris ve Filli boya reklamları da benzer kodları içermekle birlikte bir adım daha öteye giderek kullanıcı adaylarını o sanal geçekliğin içerisine tamamen dahil ederek kullanıcıların ürün ve hizmeti deneyimlemesine ve bir anlamda dijital platforma geçmesine yani dijital ve gerçek zaman arasındaki sınırı aşarak kullanıcıların gerçeğin bir adım ötesini yaşayıp deneyimlemesine ve bu ürün ve hizmet hakkında algılarının biçimlenmesine müdahale ettiğini ifade etmek yerinde olacaktır. Örnekleme dahil edilen dört reklamda da görüntü çerçevesinin içerisine dahil edilen unsurların hedef kitleyi kapsayacak biçimde düzenlendiği sanal ve gerçeği aynı platformda buluşturma noktasında başarılı olduğu, kullanıcısını aktif bir konuma getirerek o ortama dahil olma hissi yarattığ gözlenmektedir.

Bu örnek AR uygulamaları dışında Google'nın youtube üzerinden hayata geçirdiği AR uygulamaları, Volkswagen, Uber, Ikea, Pepsi max, Coca Cola, Timberland, Visa, BMW gibi dünyaca ünlü farklı sektörlerden firmaların AR uygulamalarını kullanması AR uygulamalarının online alışveriş, e- ticaret, reklam ve pazarlama alanında gelecekte daha çok yer alacağını hatta bu alanlarda belirleyici olacağının sinyallerini vermektedir. 


\section{Kaynakça}

Ağca, G., \& Kozbekçi Ayranpınar, S. (2021). Moda sektöründe $\quad$ artırılmış $\quad$ gerçeklik ve sanal gerçeklik. Yedi Sanat Tasarım ve Bilim Dergisi, 25, 1-15. https://doi.org/10.17484/yedi.731854

Akmeşe, E. (2017). Evrensel bir simgenin sıradışı öyküsü: Chevolution. H. Kuruoğlu ve A. F. Parsa (Ed.), Belgesel filmde zamanın ruhu: Belgesel filmde değişen anlam ve anlatım (s. 117-137) içinde. Detay Yayıncılık.

Akmeşe, E., \& Akmeşe, Z. (2020). Mizahla estetize edilen egemen ideolojinin tezahürü: Muhsin bey. Sosyal Beşeri ve İdari Bilimler Dergisi, 3(3), 194-207. https://doi.org/10.26677/TR1010.2020.355

Akmeşe, Z. (2020). Televizyon ana haber bültenlerinde çerçeveleme: Türk Telekom reklam filmi örneği. Middle Black Sea Journal of Communication Studies, 5(1), 37-49. https://dergipark.org.tr/en/pub/mbsjcs/issue/53358/ 702249

Alkan, M. A. (2019, 16 Mart). Sanal gerçeklik (Virtual reality). Endüstrü40. https://www.endustri40.com/sanalgerceklik-virtual-reality/

Altincik, H. (2020). Halkla ilişkiler perspektifinden medya ve yerel yönetim ilişkisi. Kriter Yayınevi.

Aziz, A. (2008). Sosyal bilimlerde araştırma yöntemleri ve teknikleri. Nobel Yayınları.

Beauty 2.0. (2016, 22 Temmuz). Make Up Genius uygulaması [Ekran Görüntüsü]. France24. https://www. france24.com/en/tv-shows/tech24/10/

Bolat, N. (2020). Televizyonun teknik dönüşümünün içeriğe etkisi. E. Sirer (Ed.), Konya televizyon 4.0 toplum 5.0 döneminde yeni izlence yeni izler kitle (s. 107-127) içinde. Literatürk Yayınevi.

Boz, M. S. (2019). Ĕ̆itimde artırılmış gerçeklik uygulamalarının değerlendirilmesi. MEB Yayınları.

Bozat A. U., \& Dedelioğlu, C. (2018, Kasım). Artırılmış gerçeklik (AR)- geleneksel ve dijitalin kâğıt üzerinde buluşması [Konferans sunumu]. 6. Uluslararası Matbaa Teknolojileri Sempozyumu, İstanbul ÜniversitesiCerrahpaşa, Türkiye.

Campaign Türkiye. (2015, 11 Mayıs). Domestos mikropları Nişantaşı'nda [Video]. Youtube. https://www.youtube.com/watch?v=j81nDoP20fI

Craig, A. B. (2013). Understanding augmented reality: Concepts and applications. Morgan Kauffman. http://digilib.stmik-banjarbaru.ac.id/data.bc/12.\%20Enterprise\%20Architecture/12.\%20Enterprise \%20Archit ecture $/ 2013 \% 20$ Understanding\%20Augmented $\% 20$ Reality.pdf

Filli Boya. (2017, 29 Mayıs). Filli boya mimar benim uygulaması [Ekran Görüntüsü]. APK-DL. https://apkdl.com/mimar-benim/com.bos4apps.mimarbenim

Foto Especial. (2018, 9 Ağustos). Kullanıcının mă̆azada test ettiği ruj renkleri [Ekran Görüntüsü]. El Sol de Toluca. https://www.elsoldetoluca.com.mx/doble-via/loreal-se-asocia-con-facebook-ofrecera-pruebasvirtuales-de-maquillaje-1903878.html

Gökçearslan, A. (2016). Artırılmış gerçeklik uygulamaları ve grafik tasarım alanına yansımaları. Turkish Studies, 11(21), 697-708. http://dx.doi.org/10.7827/TurkishStudies.11304

İçten, T., \& Bal, G. (2017a). Artırılmış gerçeklik üzerine son gelişmelerin ve uygulamaların incelenmesi. Gazi Üniversitesi Fen Bilimleri Dergisi, 5(2), 111-136. https://dergipark.org.tr/tr/pub/gujsc/issue/49772/638527

İçten T., \& Bal, G. (2017b). Artırılmış gerçeklik üzerine yapılan akademik çalışmaların içerik analizi. Bilişim Teknolojileri Dergisi, 10(4), 401-415. https://doi.org/10.17671/gazibtd.290253

Kars, N. (2003). Herkes izlesin. Derin Yayınlar1.

LC Waikiki. (t.y.). Wear 4+ uygulaması AR görüntüsü [Ekran Görüntüsü]. Apple. https://apps.apple.com/tr/app/ wear-4d/id1088231216? $=$ tr

Sirer, E. (2020). Zamanın ruhu: Eşzamansızlık. E. Sirer (Ed.), Konya televizyon 4.0 toplum 5.0 döneminde yeni izlence yeni izler kitle (s. 45-61) içinde. Literatürk Yayınevi.

Uztuğ, F. (2008). Markan kadar konuş: Marka iletişimi stratejileri. MediaCat Kitapları.

Yaşar, İ. H. (2020). Sosyal medya ve siyaset. Orion Akademi.

Yengin, D., \& Bayrak, T. (2018). Tüketimin oyunlaştırılmasıyla artırılmış gerçeklik. Etkileşim Üsküdar Üniversitesi İletişim Fakültesi Akademik Dergisi, 1, 56-77. https://doi.org/10.32739/etkilesim.2018.1.10

Yıldırım, A., \& Şimşek, H. (2013). Sosyal bilimlerde araştırma yöntemleri. Seçkin Yayıncılık.

Yılmaz, R. A. (2014). Yüzyılı dönüştüren yaratıcılar. Literatürk Yayınevi. 